\title{
Environmental influence on the bottom and near-bottom megafauna communities of the Dogger Bank: a long-term survey
}

\author{
Moritz Sonnewald • Michael Türkay
}

Received: 22 August 2011/Revised: 21 November 2011/Accepted: 24 November 2011/Published online: 9 December 2011 (C) Springer-Verlag and AWI 2011

\begin{abstract}
This paper deals with climate-driven changes of the species composition of the bottom and near-bottom megafauna of the Dogger Bank (central North Sea), which was sampled each summer with a 2 -m beam trawl on a yearly basis since 1991 . The station grid consists of 37 stations, covering an area of approximately $17.000 \mathrm{~km}^{2}$. A selection of commoner species is analysed and correlated with temperature data gained during the research period. Temperatures are derived from our own measurements, combined with CTD data from the International Council for the Exploration of the Sea. The results show a decrease in biodiversity and a clear regime shift around the beginning of the 21 st century, combined with rising mean bottom temperatures. In addition, details are given about the Dogger Bank hydrography and the climate sensitivity and abundance of the main species caught with the beam trawl. Our long-term study reveals the changes in the community structure of the megafauna of the Dogger Bank over a period of almost two decades. It suggests a link between changes in species composition/abundance and changes in the environment, especially the marine climate.
\end{abstract}

Communicated by Heinz-Dieter Franke.

M. Sonnewald $(\bowtie) \cdot$ M. Türkay

Biodiversity and Climate Research Centre (BiK-F),

Senckenberganlage 25, 60325 Frankfurt am Main, Germany

e-mail: Moritz.Sonnewald@Senckenberg.de

M. Türkay

e-mail: Michael.Tuerkay@Senckenberg.de

M. Sonnewald · M. Türkay

Senckenberg Research Institute and Natural History Museum,

Marine Zoologie, Crustaceen, Senckenberganlage 25,

60325 Frankfurt am Main, Germany
Keywords Megafauna $\cdot$ Climate sensitivity $\cdot$ Biodiversity loss $\cdot$ Beam trawl survey $\cdot$ Dogger Bank $\cdot$ North Sea

\section{Introduction}

The important role of climate-induced changes in the ecology (not only) of the marine environment is, in some cases, well documented (Ottersen et al. 2001; Stenseth et al. 2002). Climate-driven regime shifts of planktonic species have been observed in the past (Reid et al. 2003). The main driving force seems to be the continuous increase in the North Atlantic Oscillation Index, causing higher means in sea surface temperatures (SST) as well as milder winters in the northern hemisphere (Hurrell 1995; Stenseth et al. 2002). Although the influence of changing SST on the different marine trophic levels is rather complex (Kirby and Beaugrand 2009), former as well as recent studies revealed the effects of changing SST's-especially in winter - on the abundance and distribution of endobenthic (Beukema 1992; Buchanan and Moore 1986; Kröncke et al. 1998; Reiss et al. 2006; Wieking and Kröncke 2001; Ziegelmeier 1970) and epibenthic species in the North Sea (Neumann et al. 2008, 2009a).

In this study, climatic influences on faunal assemblages caught with the beam trawl have been our main focus. They mainly include epibenthic, but also demersal and endobenthic species, as well as three pelagic fishes and one hyperbenthic cephalopod (Fig. 7). Our research area, the Dogger Bank, is a sandbank in the central North Sea, covering an area of approximately $21,000 \mathrm{~km}^{2}$, with a depth range around $12-40 \mathrm{~m}$. Our research grid is located within the $30 \mathrm{~m}$ depth contour and lies in the exclusive economic zones of three countries: UK, the Netherlands and Germany. The Dogger Bank builds the northern end of 
a "southern" species community cluster with its northern edge being adjacent to faunal assemblages typical for the northern North Sea (Frauenheim et al. 1989, Jennings et al. 1999a). As introduced and summarised in Sonnewald and Türkay (2011), several detailed and ongoing studies concerning the infauna of the Dogger Bank have been undertaken ever since, but concerning the typical faunal assemblages caught by beam trawl, only sparse information was available.

The main focus of this study is to check the Dogger Bank (epi)benthic animal communities for changes in biodiversity, as well as whether there are species affected by changes in climate over the last two decades.

\section{Materials and methods}

\section{Sampling procedure}

Since 1991, numerous beam trawl samples have been collected at the Dogger Bank (North Sea) covering an area of approximately $17,000 \mathrm{~km}^{2}$ on a yearly basis (with three exceptions due to interfering projects in 1998, 2000 and 2007) during summer (July/August). The location of the research area with the station grid is shown in Fig. 1 and covers 37 stations. If possible, all stations were sampled once a year, except station 40, which was sampled with 16 tows in a 48-h period since 1994 . In some years, we could not sample all stations due to gales ( $7 \mathrm{bft}$ and above, see Table 1). On each cruise (except 2002), temperature was measured at all sampling sites using different methods. Together with the effective sampling effort per year, these are listed in Table 1. Furthermore, salinity [ppm] was measured constantly on all cruises (except 2002) and at all sites. In 2002, temperature

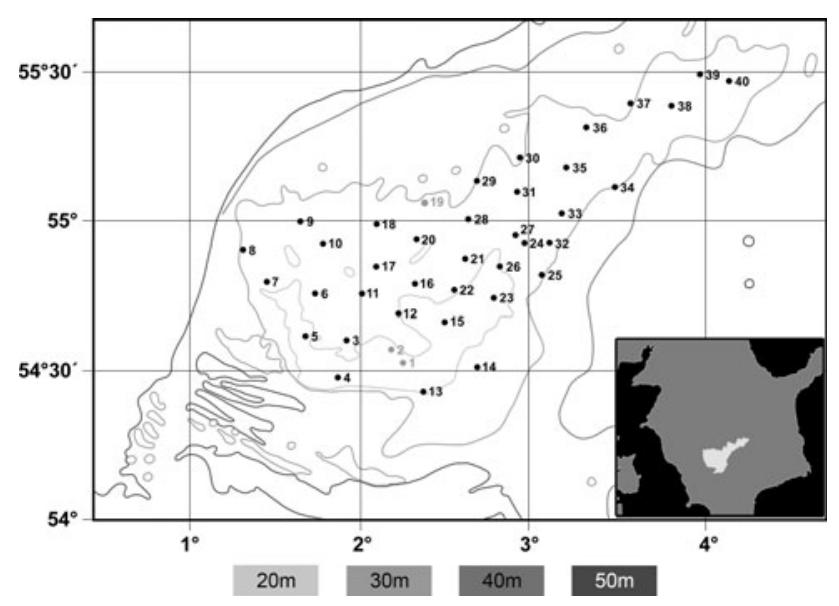

Fig. 1 Dogger Bank bathymetry map including the station grid, enhanced after Sonnewald and Türkay (2011). Stations 1, 2 and 19 were abandoned after the first cruise in 1991 due to coarse sediments, being unsuitable for beam trawl sampling and salinity records were not usable due to a calibration error. In addition, current velocity and direction were measured with a RCM9 probe in 2009.

After recording the environmental conditions, a $2-\mathrm{m}$ beam trawl with a mesh size of $1 \mathrm{~cm}^{2}$ was deployed and towed for one nautical mile at two knots on each site. Once aboard, the fauna was sieved using three different mesh sizes $(10 \mathrm{~mm}, 5 \mathrm{~mm}$ and $300 \mu \mathrm{m})$, and the fractions smaller than $1 \mathrm{~cm}^{2}$ were separated. The megafauna ( $>1 \mathrm{~cm}$, corresponding to the mesh size of the net) was then identified to species level, and the individuals were counted on board ship. The fine fractions $(<1 \mathrm{~cm})$, as well as undetermined or rare faunal elements, were preserved in $5 \%$ formaldehyde in seawater (rarely in EtOH 99\%) for laboratory determination.

\section{Diversity and distance analyses}

By combining the ship and laboratory datasets, a time-lined species abundance dataset consisting of 185 species was generated. This list (with a few exceptions) was published in Sonnewald and Türkay (2011). Only a part of all determined species was considered as generating a quantitative dataset. If a species met one or more of the following criteria, it was omitted from the list because it was considered inappropriate for statistical analysis.

- Species is not quantifiable or recorded only with relative abundances (sessile animal colonies)

- Number of individuals does not exceed 10 on any cruise

- Species is only detected on one cruise, and number of individuals is below 10

Using these restrictions, 126 of 185 species were omitted from the list, leaving 59 species, considered to be common enough and thus relevant for quantitative analysis and called SpL hereafter.

In order to determine diversity changes within the research period, the Shannon-Wiener Index $\left(\mathrm{H}^{\prime}\right)$ (Spellerberg and Fedor 2003) and the Simpson Index (D) (Simpson 1949) were calculated, using the SpL data of all cruise years.

The total abundance of each SpL species per cruise was 4th root transformed, and a multidimensional scaling plot (MDS) was generated for distance analysis, using a similarity matrix after Bray and Curtis (1957) in the software package Primer v6, in order to obtain additional information on the degree of similarity of the species composition at all cruise years.

Temperature analyses

To provide the best possible temperature resolution, surface and water column temperature data collected on our 
Table 1 Methods and range of temperature records, including sampling effort

\begin{tabular}{llllllll}
\hline Year & Samples & Gear & Range & Year & Samples & Gear & Range \\
\hline 1991 & $37(+0)$ & Dtp & su & 2001 & $37(+15)$ & Dtp & su \\
1992 & $37(+0)$ & Dtp & su & 2002 & $37(+8)$ & RCM & CTD \\
1993 & $24(+0)$ & Dtp & su, sed & 2003 & $37(+16)$ & wc \\
1994 & $37(+8)$ & Dtp & su, sed & 2004 & $37(+14)$ & Dtp & su \\
1995 & $37(+18)$ & Dtp & su, [sed & 2005 & $22(+0)$ & CTD & wc \\
1996 & $37(+16)$ & Dtp & su, sed & 2006 & $37(+16)$ & CTD & wc \\
1997 & $37(+15)$ & Dtp, CTD & su, wc & 2008 & $37(+3)$ & CTD & Dtp, RCM \\
1999 & $37(+15)$ & Dtp, CTD & [su], wc & 2009 & $37(+16)$ & su, wc \\
\hline
\end{tabular}

Columns 1 and 5: cruise years. Columns 2 and 6: number of samples per cruise. Curved brackets indicate the number of additional sampling passes (48-h sampling) on station 40. Columns 3 and 7: gear used (Dtp = Digital temperature probe; CTD = CTD probe; RCM = RCM9 probe). Columns 4 and 8: range of water body where measurement was taken ( $s u$ surface, sed sediment, wc water column). Box brackets indicate where only a minor part of stations was probed (1995 sed-11:37; 1999 su-15:37)

cruises were combined with publicly available CTD data provided online by the International Council for the Exploration of the Sea (ICES). This combined dataset (123.798 entries) was converted and analysed with the aid of the programme Ocean Data View (ODV).

The mean temperature of the water column during summer was estimated by generating a section from the north-east to the south-west of the sandbank, including the values for all years (1991-2010) from July 01 to August 31 . This technique resulted in the detection of a thermocline at approximately $15 \mathrm{~m}$. This depth was used to separate the surface and bottom layer of the water column. Thus, temperature means were calculated for the surface and bottom layer during each summer (July 01-August 31) and each year.

\section{Correlation analysis}

A Spearman's rank correlation analysis was performed, comparing the yearly abundance of each species with the mean summer bottom water temperature. The species were sorted by their Spearman's indices, from high to low.

\section{Results}

Diversity and distance analyses

The Shannon-Wiener index $\left(\mathrm{H}^{\prime}\right)$ and the Simpson index $(D)$, used as diversity indicators in Fig. 2, both show a significant diversity decrease in the mean since the year $2002(P<0.0001)$. The curves are not completely congruent (obvious in 1996 and 2003) due to differing calculation formulas.

This obvious biodiversity decrease is further supported by an MDS plot (Fig. 3), showing a considerable

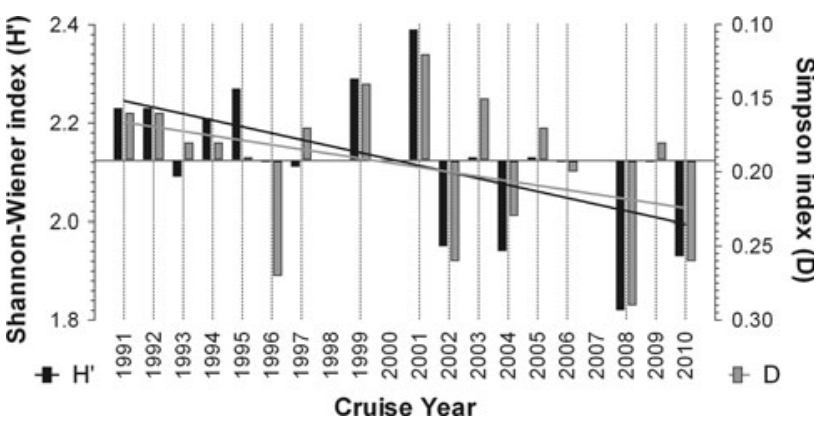

Fig. 2 Shannon-Wiener index $\left(\mathrm{H}^{\prime}\right)$ and Simpson index $(D)$ of biodiversity for all cruises, based on the list of species defined as quantitatively relevant. The graphs show the deviation from the mean $\left(\mathrm{H}^{\prime}=2.12, D=0.19\right)$. For congruence of the indices means, the right $y$-axis was inverted and the means for both indices were matched to each other. The solid (grey and black) lines depict the linear trends of both indices. No data are available for the years 1998, 2000 and 2007

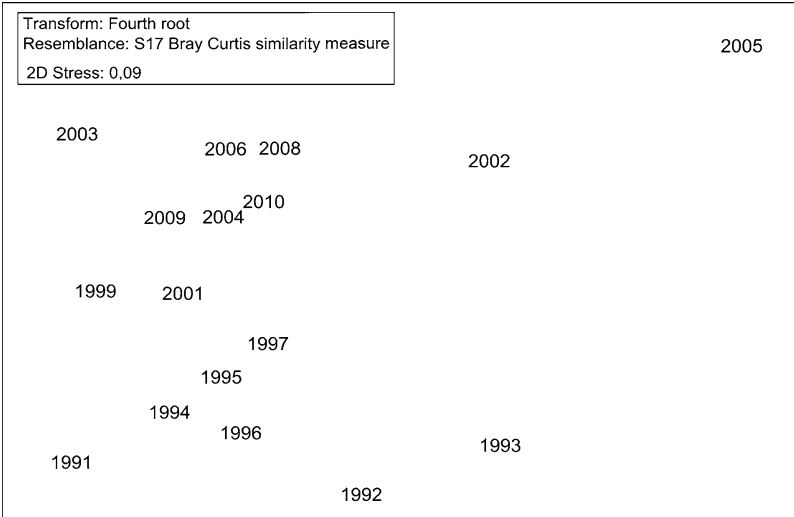

Fig. 3 MDS plot of all summer cruises, based on the total species abundances per cruise. 4th root transformed abundance data. The labels represent the cruise years 
separation of the cruises in the 1990s from those in the 2000s, regarding species composition and abundance of each cruise.

\section{Temperature analyses}

A temperature section from the north-east to the south-west of the Dogger Bank was generated with the software ODV (Figs. 4, 5) on the basis of the combined temperature dataset mentioned in "Material and Methods."

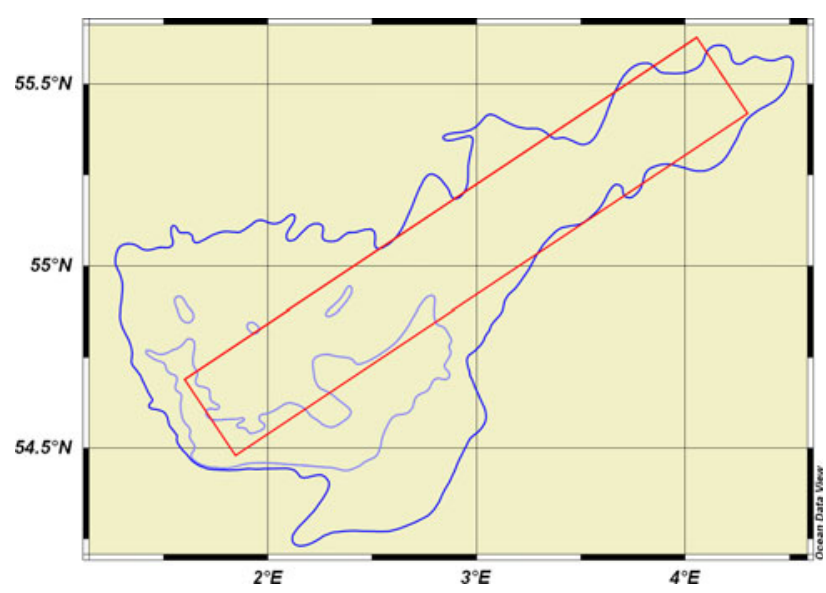

Fig. 4 Ocean Data View section across the research area. Length $\sim 100 \mathrm{~nm}$ and width $\sim 16 \mathrm{~nm}$. See Fig. 5 for further details

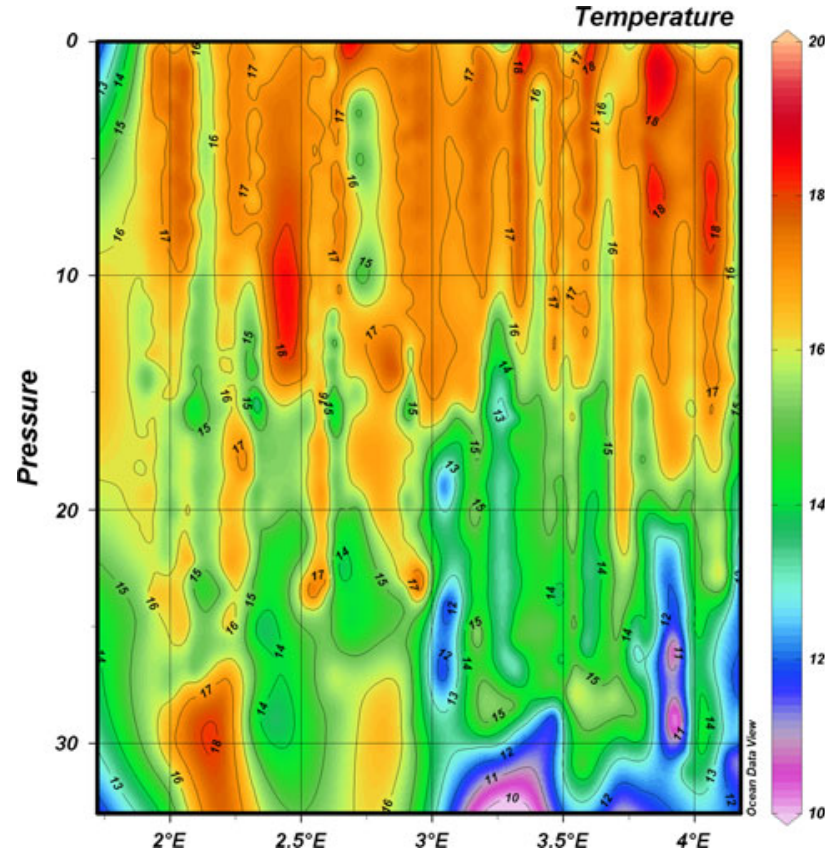

Fig. 5 Water column temperature profile of the section in Fig. 4. Interpolation of data from July 01 to August 31, years 1991-2010. Combination of ICES and own CTD data
A temperature gradient is visible from the surface to the bottom layer, with mean temperature values around a pressure of $15 \mathrm{dBar}(\sim 15 \mathrm{~m})$. This threshold was used to separate surface and bottom temperatures, resulting in the mean temperatures, respectively, for summer and total year, of the surface $(0-15 \mathrm{dBar})$ and the bottom layer (15-33 dBar), shown in Fig. 6.

All trend lines in Fig. 6 show an upward trend in the mean temperatures on a small degree scale, with the mean summer bottom temperature (MSBT) trend being significantly non-zero $(P=0.026)$ in a linear regression.

\section{Correlation analysis}

The SpL species, sorted by their associated Spearman's indices (as explained above), are shown in Fig. 7. The confidence intervals for $P=0.01$ and $P=0.05$ after Zar (1972) are included as well. The result shows the degree to which the change in abundance of the respective species is correlating with changes in the MSBTs, ranging from 0.74 to -0.51 . The major part (32 species) shows positive correlation, while 27 of the $\mathrm{SpL}$ species show a negative Spearman's index.

Considering the species at the top-end of Fig. 7, a pattern of increased abundance values per cruise can be observed in years with peaks in the water temperature means, not only concerning the MSBT. The opposite trend shows up considering species at the bottom-end of the graph. Examples are given in Fig. 8, including six species with a significant positive correlation index and one species with a significant negative correlation index.

\section{Discussion}

Diversity and distance analyses

The diversity indices in Fig. 2 exhibit a clear downward trend, at least since the year 2002. This result is further supported by a previously detected decrease in species richness across the research period (Sonnewald and Türkay 2011). Although species richness is not totally identical with biodiversity (Spellerberg and Fedor 2003), it is-together with species abundance-an important measurable key factor. Disregarding the driving forces, these results show that a decrease in biodiversity could have negative effects on the ecosystem of the Dogger Bank. Although controversially discussed by Lehman and Tilman (2000), a reduction in biodiversity could reduce the ecosystem productivity and temporal stability, which may result in an increased vulnerability regarding fisheries, invasive species and changing environmental conditions. 
Fig. 6 Mean surface and bottom temperatures per year and during summer (July 01 to August 31), derived from the combination of ICES CTD data and our own CTD data. The vertical broken lines mark the years where sampling has taken place. The linear slopes show the general trend of the mean temperatures $(P$ values-yearly means: surface 0.13 , bottom 0.66 ; summer means: surface 0.21 , bottom 0.03 .)

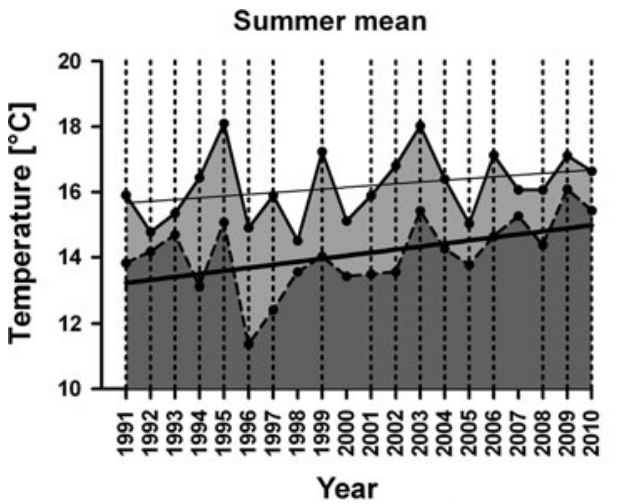

T surface

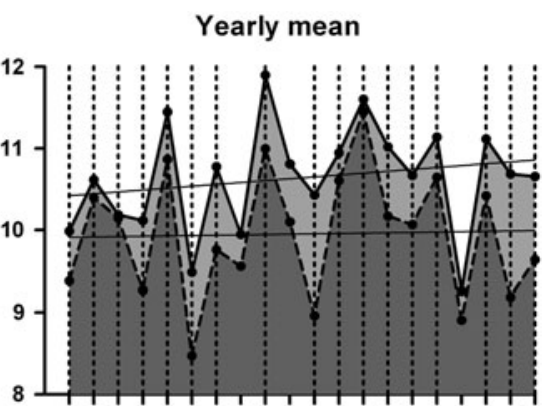

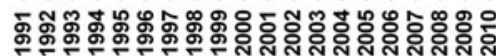

Year
Temperature analyses

As described in Kröncke and Knust (1995), the Dogger Bank hydrography is influenced by different water bodies. In summer, the south-west of the bank is characterised by an influx of warmer water from the southern North Sea and the English Channel, while the north-eastern part of the bank is under the influence of cooler water from the north. In Fig. 5, these summer temperature anomalies, the socalled "eddies" (Kröncke and Knust 1995), are visible near the bottom layer in the west $\left(2^{\circ} \mathrm{E}-2.5^{\circ} \mathrm{E}\right)$ and in the east $\left(3^{\circ} \mathrm{E}\right.$ to beyond $\left.4^{\circ} \mathrm{E}\right)$. The western temperature anomaly is caused by warmer water coming from the southern North Sea and the British Channel. The eastern anomaly is caused by the influx of cooler water from the north. The fauna reacts to this distribution of water bodies in establishing distinct communities as explained in Frauenheim et al. 1989. As shown by the distribution of animal communities through cluster analysis, the Dogger Bank is situated at the crossroad of these water bodies.

The resolution of the mean temperature per year in Fig. 6 lacks absolute accuracy, because temperature data were unavailable for some months, resulting in imprecise yearly means. Instead, the more dense summer CTD data of ICES, also supported by our own CTD data, were taken for the statistical analysis of trends.

All temperature means shown in Fig. 6 (excluding the MSBTs), only show an upwards trend but fail to pass a significance test by a linear regression. The most conclusive factor for a weak trend seemed to be the time frame of our observation. There must have been a major temperature rise of the SST just before the 1990s (O'Brien et al. 2000). For our study area, the temperatures before 1991 were not taken into account due to very sparse data availability from ICES and the lack of own CTD data. Nevertheless, clear temperature anomalies have also been detected at selected stations at the southern and northern North Sea since the beginning of the 1990s (Hughes et al. 2010), thus the observed upwards trend in our dataset seems meaningful, although some trends were non-significant.

\section{Correlation analysis}

When correlating the mean yearly water temperatures with species abundance, the first step is to verify the relevance of yearly temperature means for growth and reproduction of marine species. Literature provides several examples of marine animals showing a "reaction" to annual means in temperature. Neumann et al. (2009b) used temperature anomalies derived from mean surface and bottom temperatures for a conclusive Spearman's rank correlation with mean species abundance. Taylor (1958) showed a positive correlation of cod size/lifespan and annual means of the sea surface temperature. Perry et al. (2005) showed that temperature means are good proxies, even if winter and summer values are calculated separately, and have an effect on the distribution range of several fish species. This makes clear that isolated summer and winter values cannot explain the whole distribution characteristics. Some authors also use a restricted time frame for the analysis of specific questions, like O' Brien et al. (2000), who used the mean sea surface temperature in the period of February to June to explain cod recruitment. Again, winter to summer months are included in the period used for analysis, which shows that different times of the year have to be taken into account when discussing marine climatic influences on organisms. In consequence, we use yearly mean temperatures for our correlation analysis, as these reflect the temperature range of an entire year.

Figure 7 demonstrates that there is a distinction between species correlating positively and species correlating negatively with increasing temperatures, as well as a central cluster of species, showing no significant correlation with the MSBTs concerning their abundance. The animal with the most positive Spearman's correlation index is Luidia sarsi. In the study area, this species was first observed with 


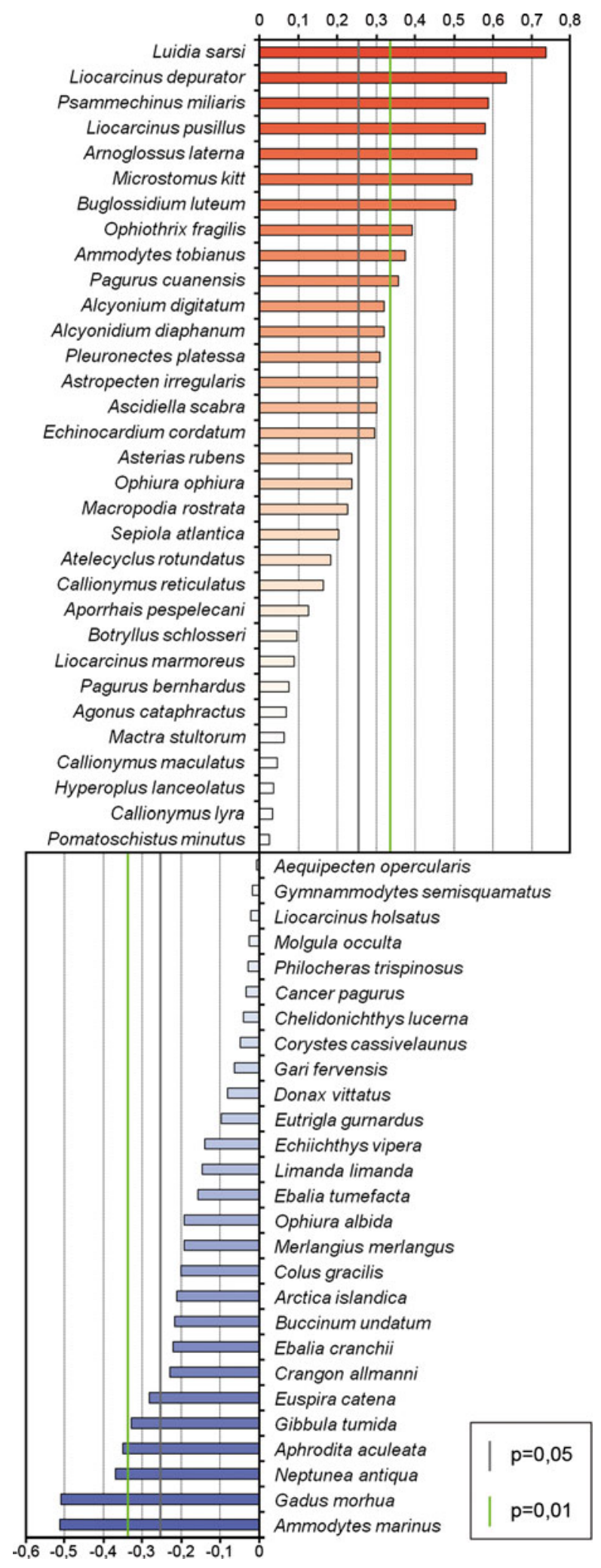

Fig. 7 Correlation indices after Spearman. The number of individuals was correlated with temperatures (sum of summer and yearly temperatures, surface and bottom layers) after Spearman. The vertical lines represent the confidence intervals $(P=0.05: \pm 0.259 ; P=0.01$ : $\pm 0.337)$ after Zar (1972) a sudden and high abundance in the year 2003, where we also observed a temperature peak in the summer and yearly means (Figs. 6, 8). Maybe this comparatively warm year was one among other factors facilitating the establishment of $L$. sarsi at the Dogger Bank. Its yearly abundance decreased again in the following years, with a smaller peak in 2009 , correlating with a smaller rise in temperatures than in 2003. Concerning its further distribution, this species is not uncommon to the North Sea, but according to Frauenheim et al. (1989), it is common in the northern regions but rare in the southern ones of the North Sea. This is supported by observations on benthic material sampled North Sea wide on the ZISCH Cruises by RV Valdivia (Frauenheim et al. 1989). It is most likely that $L$. sarsi formerly used the northern introduction route into the North Sea (Shetlands/Orkneys), because it is not found until today at the eastern British Channel and the area south of the Dogger Bank. In addition to the west coast of the British Isles, the species is reported from the Mediterranean and the Azores (Hayward and Ryland 1998; Mifsud et al. 2009). Even if this species correlates with comparatively higher temperatures, there is no clear indication that temperature is the only driving force promoting the establishment of $L$. sarsi on the Dogger Bank.

Luidia sarsi is followed by Liocarcinus depurator, a swimming crab with a distribution range from the east Atlantic coast of North-West Africa to the Hebrides, being common in the North Sea and the Mediterranean (Christiansen 1969; d'Udekem d'Acoz 1999). In our study, it first appeared in 1999 on the Dogger Bank. Since then, its abundance tended to go up with a first peak in 2003 and a second one in 2009, but in summer 2010, its abundance decreased again remarkably. One possible reason is the effects of the cold winter of 2009/2010.

The echinoderm Psammechinus miliaris has been common at the Dogger Bank since the beginning of our study, but its abundance also seems to positively correlate with temperature peaks, at least in 2003 and 2009, where it was recorded with a high number at several stations.

The flatfishes Arnoglossus laterna and Buglossidium luteum are two of the main faunal elements of the Dogger Bank, usually being present on all stations. The yellow sole B. luteum dominates most of the catches, on average being 13 times as numerous as A. laterna. Both flatfishes correlate with elevated temperatures, maybe due to a better food supply caused by a higher primary production in the food web in warmer years (Kirby and Beaugrand 2009). In addition, $A$. laterna shows a significant $(P=0.0001)$ increase in the number of individuals per year over the research period.

The species with the most negative Spearman's rank, the lesser sandeel Ammodytes marinus, shows an inverted abundance trend. This species is common in the North 

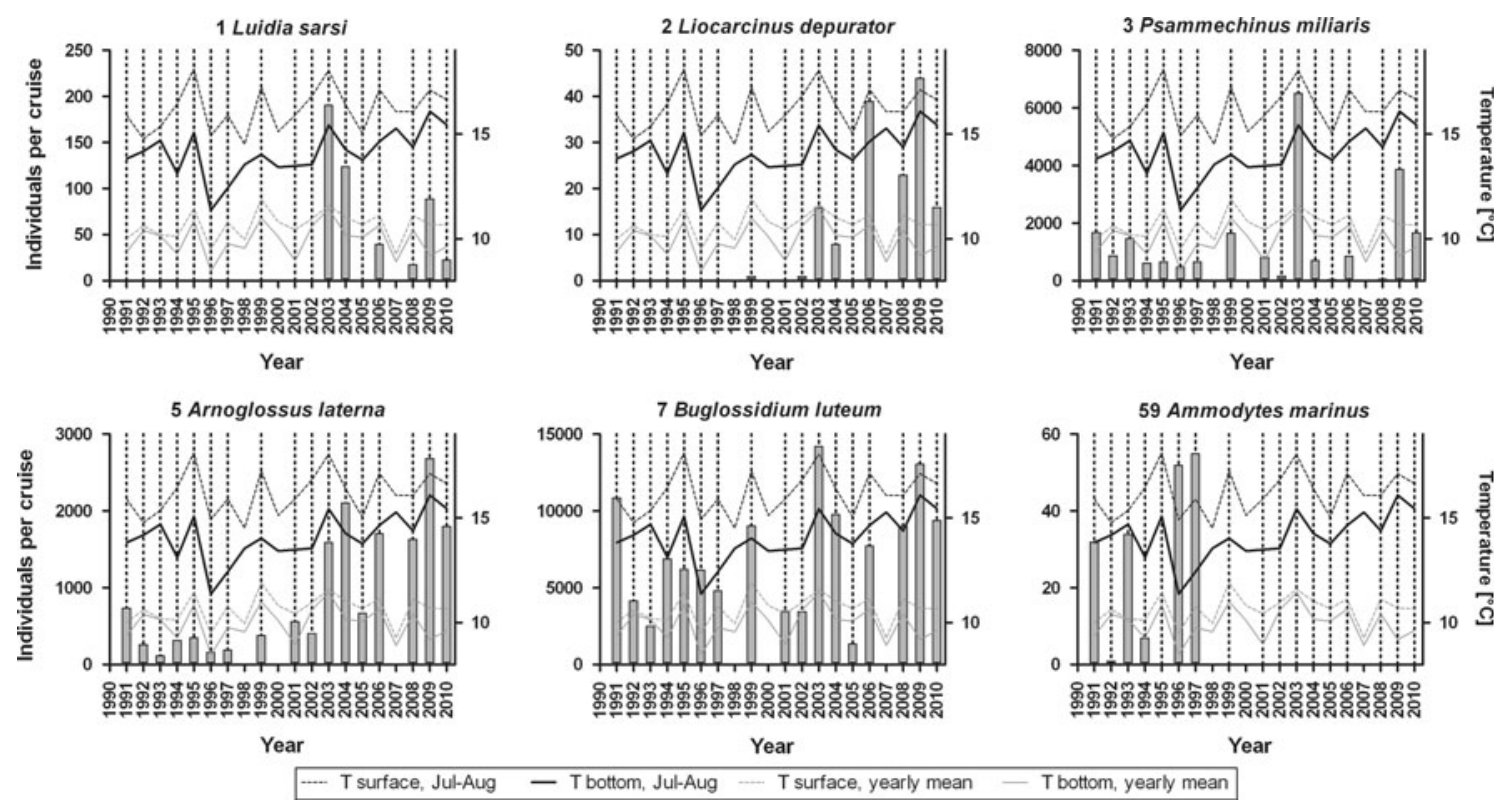

Fig. 8 Species abundance per cruise year. No. 1-3: species with the most positive Spearman's rank correlation to the temperature data. No. 5 and 7: species positively correlated with temperature data,

Atlantic up to eastern Greenland, Iceland, the Barents Sea and the North Sea (Kaschner et al. 2008). After an initial period of high abundance during the first years (1991-1997) of our long-term research, this species vanished from our catches. In contrast to the increasing abundance of some southern fish (Beare et al. 2004), the sandeel A. marinus showed the opposite trend during our study period. Its disappearance correlates with rising temperatures, but the effect of commercial fisheries on A. marinus as a target species cannot be disregarded (Pedersen et al. 1999). In the east of the Dogger Bank, this species was recorded via echosounder acoustic data by Van der Kooij et al. (2008) in the years 2004, 2005 and 2006. We cannot confirm these data obtained by echosounding through our sampling efforts. Since 1999, we were not able to catch any individuals of A. marinus. This corresponds to a dramatic decrease in sandeel landings, reported by ICES (2010, Fig. 6.4.21.2). During the period in question, we only detected a few specimens of Ammodytes tobianus, a close relative of $A$. marinus. The overall picture shown through the analysis of catch data confirms the negative correlation of sandeel abundance with rising temperatures.

General discussion

A number of kinds of impacts have been discussed in the ecological literature as possible structuring features for the epibenthic and near-bottom communities. These will be discussed here in detail with reference to the Dogger Bank. selected because of their status of being the most abundant fish species in the mean. No. 59: species with the most negative Spearman's rank correlation to the temperature data

Trawling disturbance

Little is known concerning trawling (or fishing) efforts at the Dogger Bank. Overall, only an estimation of trawling frequency seems possible for the Dogger Bank area. The works of Jennings and Kaiser (1998) and Jennings et al. (1999b, 2000) characterise the Dogger Bank as a medium- to less-affected fishing zone compared with other areas of the North Sea, with a slight decrease in trawling effort from 1990 to 1995. As mentioned in Jennings et al. (1999b), the trawling data of Belgium and France are not included in these reports due to unavailability. Jennings et al. (2001) also examined two areas adjacent to the Dogger Bank (Hills and Silver Pit) and correlated sampled biomass with trawler sightings by fishery protection flights in a 5-year time frame. This study revealed a trawling intensity of up to 6,5 times a year, resulting in highly significant decreases in bivalve and spatangoid infauna. For the epifauna, no significant correlation of trawling and biomass was detected in their work. Kröncke (1992) states that for benthic community changes at the Dogger Bank, damage by fishery is an unimportant factor. Even the sandeel fishery is regarded as an exercise with light gear, seasonally restricted to spring, resulting in weak sea floor damage. We conclude that the possible effect of trawling cannot be stronger for the epifauna than the endofauna. Therefore, we cannot see any serious impact that could be used for the interpretation of our data. 


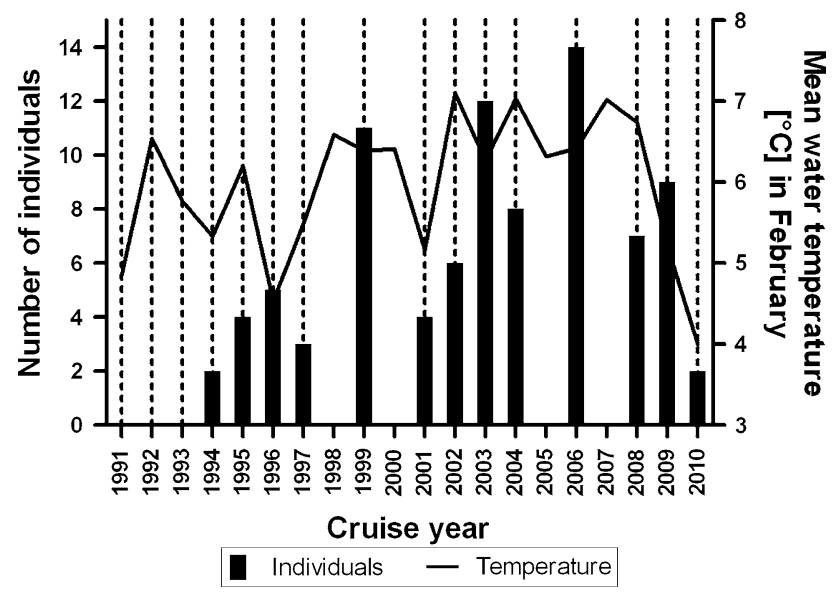

Fig. 9 Echichthys vipera. Number of individuals caught in a 48-h time frame at station 40, during summer of the years 1991-2010 (no data available for the years 1998, 2000 and 2007)

\section{Low winter temperatures}

Severe winter temperatures can have direct effects on specific epibenthic species or whole faunal assemblages, as demonstrated by Neumann et al. (2009a). For the Dogger Bank, the example of the lesser weever, Echiichthys vipera, exemplifies species directly affected by water temperature. We compared the species' summer abundance data at our permanent station (station 40), where sampling takes place for every $3 \mathrm{~h}$ during a 48-h period (Fig. 9). Echiichthys vipera is a species that was always present at the western part of our research area since the beginning of our studies in 1991. The species was not present before 1994 at the north-eastern tail end, which has cooler yearly mean water temperatures as compared to the west. After 1994, the number of individuals caught on station 40 increased and generally followed the trend of the mean water temperatures in winter across the entire Dogger Bank (February water temperature data averaged from the ICES CTD dataset). On a research cruise with RV Heincke in February 2010, after a severe and long winter, we measured a mean temperature of $4,00^{\circ} \mathrm{C}$ (own CTD data taken across the research area) and caught only one specimen. The assumed scarcity of the weever was in good accordance with the results in summer 2010, where only two juvenile individuals of E. vipera were caught at station 40 in contrast to 4-14 individuals (average value $=8.5$ ) in former years (2001-2009).

Another example is the bivalve Arctica islandica. The growth rings of its shell are a good index for climatic events, impressively demonstrated by Schöne et al. (2003, 2005). Additionally, the shell of A. islandica together with the shells of Mya truncata and Chamelea striatula can be used to show sediment re-suspension strength due to storms, as shown by Witbaard et al. (2005).

\section{Conclusions}

The results of this study show clearly that water temperature is a significant factor for explaining species abundances and composition of the bottom fauna of the Dogger Bank. In our study area, factors like fishing pressure seem to play a minor role compared to long-term temperature shifts. It was apparent that species appearance and disappearance (presence-absence events) do not constitute the totality of observable changes, but there are clear positive and negative correlations of the abundance of individual species with a particular temperature regime. Appearance and disappearance of species would thus be the extreme ends of a scale of increase and decrease. These correlations were detected by the analysis of long time series, and it will be of great interest to see how the species with a positive or negative correlation towards warmer temperatures will move on the scale and when they will possibly drop out or get more abundant. These events can only be followed up by ongoing long-term monitoring.

Acknowledgments We thank the Biodiversity and Climate Research Centre (BiK-F) in Frankfurt am Main for funding our work and data analysis, as well as the International Council for the Exploration of the Sea for providing such detailed CTD data. We also thank the crew (the old sea bears as well as the newcomers) of the research vessel Senckenberg, who always gave and still give their best for our cruises to succeed. Special thanks go to Dr. R.G. Hartnoll for proofreading of the manuscript for this publication.

\section{References}

Beare DJ, Burns F, Greig A, Jones EG, Peach K, Kienzle M, McKenzie E, Reid DG (2004) Long-term increases in prevalence of North Sea fishes having southern biogeographic affinities. Mar Ecol Prog Ser 284:269-278

Beukema J (1992) Expected changes in the Wadden Sea benthos in a warmer world: lessons from periods with mild winters. Net J Sea Res 30:73-79. doi:10.1016/0077-7579(92)90047-I

Bray JR, Curtis JT (1957) An ordination of the upland forest communities of Southern Wisconsin Ecol Monogr 27(4):325. stable http://www.jstor.org/stable/1942268

Buchanan JB, Moore JJ (1986) Long-term studies at a benthic station off the coast of Northumberland. Hydrobiologia 142(1):121127. doi: $10.1007 / \mathrm{BF} 00026752$

Christiansen ME (1969) Crustacea Decapoda Brachyura. Marine invertebrates of Scandinavia, vol 2, Universitetsforlaget, Oslo

Frauenheim K, Neumann V, Thiel H, Türkay M (1989) The distribution of the larger epifauna during summer and winter in the North Sea and its suitability for environmental monitoring. Senck Marit 20(3/4):101-118

Hayward PJ, Ryland JS (1998) Handbook of the marine fauna of North-West Europe. Oxford University Press, New York

Hughes SL, Holliday NP, Beszczynska-Möller A (2010) ICES report on ocean climate 2009. ICES cooperative research report no. 304:1-67

Hurrell JW (1995) Decadal trends in the North Atlantic oscillation: regional temperatures and precipitation. Science 269(5224):676679. doi:10.1126/science.269.5224.676 
ICES (2010) Report of the ICES advisory committee 2010. ICES advice, 2010. Book 6, 1-309. Available online at: http://www. ices.dk/products/icesadvice/2010/ICES\%20ADVICE\%202010\% 20Book\%206.pdf Accessed 05 Dec 2011

Jennings S, Kaiser MJ (1998) The effects of fishing on marine ecosystems. Adv Mar Biol 34:201-352

Jennings S, Lancaster J, Woolmcr A, Götter J (1999a) Distribution, diversity and abundance of epibenthic fauna in the North Sea. J Mar Biol Ass UK 79:385-399

Jennings S, Alsvåg J, Cotter A, Ehrich S, Greenstreet S, JarreTeichmann A, Mergardt N, Rijnsdorp A, Smedstad O (1999b) Fishing effects in northeast Atlantic shelf seas: patterns in fishing effort, diversity and community structure. III. International trawling effort in the North Sea: an analysis of spatial and temporal trends. Fish Res 40:125-134. doi:10.1016/S01657836(98)00208-2

Jennings S, Warr KJ, Greenstreet SPR, Cotter AJR (2000) Spatial and temporal patterns in North Sea fishing effort. In: Kaiser MJ et al (eds) The effects of fishing on non-target species and habitats: biological, conservation and socio-economic issues. Fishing News Books Blackwell, UK, pp 3-14

Jennings S, Pinnegar J, Polunin N, Warr K (2001) Impacts of trawling disturbance on the trophic structure of benthic invertebrate communities. Mar Ecol Prog Ser 213:127-142. doi: 10.3354/meps 213127

Kaschner K, Ready JS, Agbayani E, Rius J, Kesner-Reyes K, Eastwood PD, South AB, Kullander SO, Rees T, Close CH, Watson R, Pauly D, Froese R (2008) AquaMaps: predicted range maps for aquatic species. http://www.aquamaps.org/preMap 2.php? cache $=1 \&$ SpecID=Fis-29267, version 08/2010. Accessed 05 Dec 2011

Kirby RR, Beaugrand G (2009) Trophic amplification of climate warming. Proc R Soc B 276(1676):4095-4103. doi:10.1098/rspb.2009.1320

Kröncke I (1992) Macrofauna standing stock of the Dogger Bank. A comparison: III. 1950-54 versus 1985-87. A final summary. Helgoland Mar Res 46:137-169

Kröncke I, Knust R (1995) The Dogger Bank: a special ecological region in the central North Sea. Helgoland Mar Res 49:335-353. doi:10.1007/BF02368361

Kröncke I, Dippner JW, Heyen H, Zeiss B (1998) Long-term changes in macrofaunal communities off Norderney (East Frisia, Germany) in relation to climate variability. Mar Ecol Prog Ser 167:25-36. doi:10.3354/meps167025

Lehman CL, Tilman D (2000) Biodiversity, stability, and productivity in competitive communities. Am Nat 156:534-552. doi: $10.1086 / 303402$

Mifsud C, Taviani M, Stöhr S (2009) Remarks on Echinodermata from the South Central Mediterranean Sea based upon collections made during the MARCOS cruise (10 to 20th April, 2007). Mediterr Mar Sci 10:63-71

Neumann H, Ehrich S, Kröncke I (2008) Effects of cold winters and climate on the temporal variability of an epibenthic community in the German Bight. Clim Res 37:241-251. doi:10.3354/ cr00769

Neumann H, Reiss H, Rakers S, Ehrich S, Kröncke I (2009a) Temporal variability in southern North Sea epifauna communities after the cold winter of 1995/1996. ICES J Mar Sci 66(10):1-11. doi:10.1093/icesjms/fsp203

Neumann H, Ehrich S, Kröncke I (2009b) Variability of epifauna and temperature in the northern North Sea. Mar Biol 156:1817-1826. doi:10.1007/s00227-009-1215-0

O'Brien CM, Fox CJ, Planque B, Casey J (2000) Climate variability and North Sea cod. Nature 404(6774):142. doi:10.1038/350 04654
Ottersen G, Planque B, Belgrano A, Post E, Reid PC, Stenseth NC (2001) Ecological effects of the North Atlantic oscillation. Oecologia 128(1):1-14. doi:10.1007/s004420100655

Pedersen S, Lewy P, Wright P (1999) Assessments of the lesser Sandeel (Ammodytes marinus) in the North Sea based on revised stock divisions. Fish Res 41(3):221-241

Perry AL, Low PJ, Ellis JR, Reynolds JD (2005) Climate change and distribution shifts in marine fishes. Science 308:1912-1915. doi: 10.1126/science. 1111322

Reid PC, Edwards M, Beaugrand G, Skogen M, Stevens D (2003) Periodic changes in the zooplankton of the North Sea during the twentieth century linked to oceanic inflow. Fish Oceanogr 12(4-5):260-269. doi:10.1046/j.1365-2419.2003.00252.x

Reiss H, Meybohm K, Kröncke I (2006) Cold winter effects on benthic macrofauna communities in near- and offshore regions of the North Sea. Helgoland Mar Res 60(3):224-238. doi: 10.1007/s10152-006-0038-3

Schöne BR, Kröncke I, Houk SD, Castro ADF, Oschmann W (2003) The cornucopia of chilly winters: Ocean quahog (Arctica islandica L., Mollusca) master chronology reveals bottom water nutrient enrichment during colder winters (North Sea). Senck marit 32:165-175. doi:10.1007/BF03043092

Schöne BR, Pfeiffer M, Pohlmann T, Siegismund F (2005) A seasonally resolved bottom-water temperature record for the period AD 1866-2002 based on shells of Arctica islandica (Mollusca, North Sea). Int J Climatol 25:947-962. doi: $10.1002 /$ joc. 1174

Simpson E (1949) Measurement of diversity. Nature 163:688. doi: $10.1038 / 163688 \mathrm{a} 0$

Sonnewald M, Türkay M (2011) The Megaepifauna of the Dogger Bank (North Sea): species composition and faunal characteristics 1991-2008. Helgoland Mar Res. doi:10.1007/s10152-011-0247-2

Spellerberg IF, Fedor PJ (2003) A tribute to Claude Shannon (1916-2001) and a plea for more rigorous use of species richness, species diversity and the Shannon-Wiener Index. Global Ecol Biogeogr 12(3):177-179. doi:10.1046/j.1466-822X.2003.00015.x

Stenseth NC, Mysterud A, Ottersen G, Hurrell JW, Chan K, Lima M (2002) Ecological effects of climate fluctuations. Science 297(5585):1292-1296. doi:10.1126/science.1071281

Taylor C (1958) Cod growth and temperature. J Conseil 23:366-370

Udekem d' Acoz C 'd (ed) (1999) Inventaire et distribution des crustacés décapodes de l'atlantique nord-oriental, de la méditerranée et des eaux continentales adjacentes au nord de $25^{\circ} \mathrm{N}$. Patrimoines naturels (Mus Natl Hist Nat/Serv Patrimoine Nat) 40

Van der Kooij J, Scott B, Mackinson S (2008) The effects of environmental factors on daytime sandeel distribution and abundance on the Dogger Bank. J Sea Res 60(3):201-209. doi: 10.1016/j.seares.2008.07.003

Wieking G, Kröncke I (2001) Decadal changes in macrofauna communities on the Dogger Bank caused by large-scale climate variability. Senck Marit 31(2):125-141. doi:10.1007/BF03043023

Witbaard R, Duineveld G, Amaro T, Bergman M (2005) Growth trends in three bivalve species indicate climate forcing on the benthic ecosystem in the southeastern North Sea. Clim Res 30:29-38. doi:10.3354/cr030029

Zar J (1972) Significance testing of the Spearman rank correlation coefficient. J Am Stat Assoc 67:578-580

Ziegelmeier E (1970) Über Massenvorkommen verschiedener makrobenthaler Wirbelloser während der Wiederbesiedlungsphase nach Schädigungen durch "katastrophale"Umwelteinflüsse. Helgoland Mar Res 21(1-2):9-20. doi:10.1007/BF01630517 